\title{
A unique off-on near-infrared cyanine-based probe for imaging of endogenous alkaline phosphatase activity in cells and in vivo
}

\author{
Zhiwei Gao $^{\mathrm{a}, \mathrm{b}}$, Jingya Sun ${ }^{\mathrm{a}}$, Min Gao ${ }^{\mathrm{b}, \mathrm{c}}$, Fabiao $\mathrm{Yu}^{\mathrm{a}, \mathrm{b}, *}$, Lingxin Chen ${ }^{\mathrm{a}, \mathrm{b}, *}$, Qingguo Chen ${ }^{\mathrm{a}, *}$ \\ a College of Marine Science and Technology, Zhejiang Ocean University, Zhoushan 316004, China \\ ${ }^{\mathrm{b}}$ Key Laboratory of Coastal Environmental Processes and Ecological Remediation, Research Center for Coastal Environmental Engineering and Technology, \\ Yantai Institute of Coastal Zone Research, Chinese Academy of Sciences, Yantai 264003, China \\ ${ }^{\mathrm{C}}$ University of Chinese Academy of Sciences, Beijing 100049, China
}

\section{A R T I C L E I N F O}

\section{Article history:}

Received 9 December 2017

Received in revised form 7 March 2018

Accepted 14 March 2018

Available online 15 March 2018

\section{Keywords:}

Alkaline phosphatase

Fluorescent probes

Near-infrared fluorescence

In vivo imaging

\begin{abstract}
A B S T R A C T
Alkaline phosphatase (ALP) is a class of enzymes that are widely found in various tissues of the human body. It plays important roles in regulating diverse cellular functions. The aberrant levels of serum ALP are implicated in diseases. The development of sensitive and accurate detection tool for evaluating the level changes of ALP in living organisms will be very helpful in the fields of biochemistry, cytology and clinical medicine. Herein, we develop a near-infrared probe (QcyP) for the specific detection of different ALP levels both in different cell lines and in tumor-bearing mice models. The probe is composed of two moieties: a unique heptamethine cyanine fluorophore and a phosphate monoester. ALP can trigger an off-on fluorescence switch via an enzyme-catalyzed cleavage of the phosphate group. The fluorescence regulation mechanism is based on the rearrangement of the conjugated $\pi$-electron system. The probe exhibits high selectivity and good sensitivity towards ALP. The results demonstrate that the probe QcyP not only can be applied to discriminate the levels of ALP in different cell lines, but also can distinguish the ALP level changes between hepatic tumor mice model and normal mice.
\end{abstract}

(c) 2018 Elsevier B.V. All rights reserved.

\section{Introduction}

Phosphatases are a large and structurally diverse family of signaling enzymes which can remove the phosphate group from protein and nonprotein substrates [1]. Among the various types of phosphatases, alkaline phosphatase (ALP) is the most common and crucial subclass, as it regulates biofunctions in the biogeochemical cycle of phosphorus [2]. ALP not only facilitates the hydrolysis of monoesters of phosphoric acid but also participates in transphosphorylation reaction in the presence of high concentrations of phosphate acceptors [2]. ALP widely exists in organisms from bacteria to eukaryotes [2]. In human, ALP involves in abundant isozymes, including intestinal alkaline phosphatase (IAP), placental alkaline phosphatase (PLAP), germ cell alkaline phosphatase (GCALP) and tissue non-specific alkaline phosphatase (TNAP). Especially, TNAP holds high expression level in liver, bone, kidney, as

\footnotetext{
* Corresponding authors at: College of Marine Science and Technology, Zhejiang Ocean University, Zhoushan 316004, China.

E-mail addresses: fbyu@yic.ac.cn (F. Yu), lxchen@yic.ac.cn (L. Chen), qgchen@zjou.edu.cn (Q.Chen).
}

well as other tissues [3]. ALP behaves important roles in protein cyclic metabolism of phosphorylation and dephosphorylation in cells. It is well documented that the increase of endogenous ALP activity is closely related to the proliferation and differentiation of osteoblasts and bone mineralization [4]. Moreover, accumulating clinical manifestations suggest that the aberrant elevation of serum ALP level and activity is associated with many diseases, such as breast cancer, prostatic cancer, liver dysfunctions, intestinal diseases, bone diseases, and diabetes [2-5]. Therefore, the biological and chemical approaches must be developed to detect the expression level of ALP. And more importantly, the examination of ALP activity can provide invaluable insights into how it works under physiological settings and how it is modulated therapeutically under pathological conditions. Although extensive researches have been began from 1907, there still exist huge challenges for comprehending the complicated and confused cellular phosphoproteome network. The main obstacle is lacking of desirable chemical tools which are capable of in real-time investigating protein dephosphorylation in cells and in vivo [4]. Thence, it is necessary to establish a reliable, simple and sensitive method for ALP detection in biological systems. 


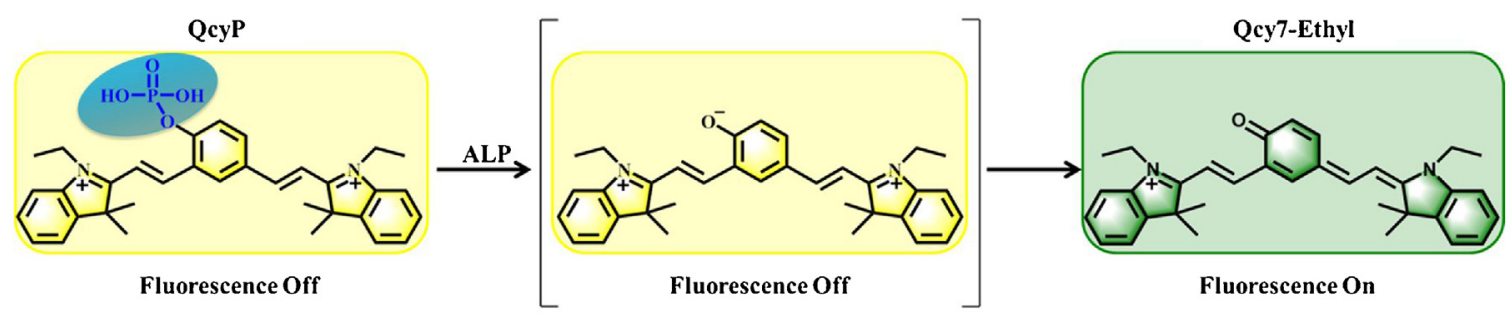

Scheme 1. Illustration of molecular structure and detection mechanism of QcyP towards ALP.

Recently, biological and chemical approaches have been developed for inspecting the expression level and activity of endogenous ALP, such as those based on electrochemistry, chromatography, colorimetric techniques and peptide microarray [6-9]. However, these detection technologies fail to provide an adequate view of ALP dynamic properties by high sensitivity, real-time detection, and high spatial resolution imaging in live samples [10,13]. Fluorescence imaging-based approaches have emerged to address some of these issues via focusing on the detection of ALP activities in cells at the proteome level [10-28]. Among them, small-molecule-based fluorescent probes are highly desirable due to their desirable chemical modification, excellent biocompatibility, and low cost [29]. Despite the promising properties of small-molecule probes offer effective and versatile utilizations to specific detection of ALP in complex proteomes (i.e., cell lysates) and living cells [30-35], but many of them are not suitable for deep imaging in tissues and animals owing to their short emission wavelength at UV-vis region, which hinders their further applications in biological systems. However, near-infrared (NIR) fluorescence bioimaging probes with NIR absorption and emission profiles (650-900 nm) can penetrate tissue more deeply and minimize the interference from background autofluorescence, which greatly facilitates for imaging of physiological processes in vivo [36,37]. Until now, only one hemicyanine-based NIR probe has been employed for the detection of ALP in vivo [10,13]. However, the fluorescent probe that can penetrate deeper tissue for ALP detection is still urgent need. Therefore, it is full of interest and anticipation to further exploit the development of new NIR fluorescent probe for detection of ALP in cells and in vivo.

Herein, we designed and synthesized a NIR fluorescent probe (QcyP) for selective evaluation of ALP enzymatic activity in various different living cells and mice models (Scheme 1). Based on a unique NIR fluorescent fluorophore QCy7-Ethyl, the probe showed an off-on fluorescence signal change with depending on the enzyme-substrate (ES) interaction. The results of kinetic experiments revealed that our probe possessed high binding capacity for ALP. We also evaluated the levels of ALP activities in eight human cell lines using QcyP. Finally, we successfully applied QcyP to compare the real-time process of ALP dynamic dephosphorylation in normal and HepG2 tumor-bearing mice.

\section{Experimental}

\subsection{Synthesis of QcyP}

The commercially available compound 4,4Hydroxyisophthalaldehyde (50 mg, $0.33 \mathrm{mmol}$ ) and compound 3 (220.5 mg, $0.70 \mathrm{mmol}$ ) were dissolved in $150 \mathrm{~mL}$ mixed solution $n$-butyl alcohol/toluene $(7: 3, \mathrm{v} / \mathrm{v})$. The mixture was refluxed for $3 \mathrm{~h}$, and the reaction was monitored by TLC. Then the solvent was removed in vacuum. The crude product was dissolved into $100 \mathrm{~mL}$ $\mathrm{CH}_{2} \mathrm{Cl}_{2}$, and washed with $\mathrm{H}_{2} \mathrm{O}(100 \mathrm{~mL} \times 3)$. The organic layer was separated and concentrated. The silica gel column chromatography was used for the further purification. The eluent was EtOAc/ $\mathrm{CH}_{3} \mathrm{OH}$ $(3: 1, v / v)$. The final product Qcy7-Ethyl was a green solid, yield 70\%. ${ }^{1} \mathrm{H}$ NMR (500 MHz, DMSO-d 6 ) $\delta(\mathrm{ppm}): 8.72(\mathrm{~s}, 1 \mathrm{H}), 8.43-8.42$ (d, 1H), 8.00-7.99 (d, 1H), 7.91-7.68 (m, 4H), 7.66-7.50 (m, 4H), 6.95-6.93 (d, 1H), 6.80-6.77 (t, 1H), 6.63-6.62 (d, 1H), 6.60-5.98 $(\mathrm{d}, 1 \mathrm{H}), 3.35-3.28(\mathrm{~m}, 3 \mathrm{H}), 3.23-3.16(\mathrm{~m}, 1 \mathrm{H}), 1.91-1.83(\mathrm{~m}, 12 \mathrm{H})$, $1.79(\mathrm{~s}, 6 \mathrm{H}) .{ }^{13} \mathrm{C}$ NMR $\left(125 \mathrm{MHz}, \mathrm{CDCl}_{3}\right) \delta(\mathrm{ppm}): 184.85,183.02$, $168.56,151.39,143.87,143.63,143.51,142.16,142.07,138.87$, $134.92,130.35,130.11,126.27,123.62,123.40,123.32,120.31$, 115.03, 114.77,112.87, 109.99, 51.54, 49.93, 45.02, 44.96, 26.51, 25.32, 11.53, 10.52. LC-MS (ESI $\left.{ }^{+}\right): \mathrm{C}_{34} \mathrm{H}_{37} \mathrm{~N}_{2} \mathrm{O}^{+}$calcd. 489.2900, found $[\mathrm{M}]^{+}: 489.2906$.

Qcy7-Ethyl (25 mg, $5 \mathrm{mmol}$ ) was dissolved in $15 \mathrm{~mL}$ pyridine and then phosphorus oxychloride $(10 \mu \mathrm{L}, 5 \mathrm{mmol})$ was dropped into the mixed solution at $25^{\circ} \mathrm{C}$. After stirred for $0.5 \mathrm{~h}, 5 \mathrm{~mL} \mathrm{H}_{2} \mathrm{O}$ was added into the reaction system for another $0.5 \mathrm{~h}$. Finally, the mixture was removed by rotary evaporator. The crude product was dissolved in the mixture of $\mathrm{CH}_{2} \mathrm{Cl}_{2}(100 \mathrm{~mL})$ and $\mathrm{H}_{2} \mathrm{O}(100 \mathrm{~mL})$. The water phase was collected and concentrated under reduced pressure. The target product were purified by reversed phase silica $\mathrm{C} 18$ chromatographic column $\left(75 \% \mathrm{CH}_{3} \mathrm{OH} / \mathrm{H}_{2} \mathrm{O}\right)$. The probe QcyP was afforded as a yellow solid, yield 60\%. ${ }^{1} \mathrm{H}$ NMR $(500 \mathrm{MHz}$, DMSO- $\left.d_{6}\right) \delta$ (ppm): 9.07-9.03 (m, 2H), 8.60-8.45 (m, 2H), 8.27-8.04 (m, 3H), 7.68-7.41 (m, 4H), $7.026 .82(\mathrm{~m}, 3 \mathrm{H}), 6.26-6.25(\mathrm{~d}, 1 \mathrm{H})$, 4.61-4.43 (m, 4H), 1.99-1.78 (m, 18H). ${ }^{13} \mathrm{C} \mathrm{NMR}\left(125 \mathrm{MHz}, \mathrm{CDCl}_{3}\right)$ $\delta(\mathrm{ppm}): 183.99,183.22,154.40,147.32,145.12,144.40,144.03$, $142.03,142.00,133.40,133.33,131.50,131.25,130.55,129.98$, $127.24,127.07,124.99,123.28,115.98,115.88,100.06,54.32,53.42$, 53.36, 26.10, 26.05, 13.96, 13.52. ${ }^{31} \mathrm{P}$ NMR (150 MHz, DMSO- $\left.d_{6}\right) \delta$ (ppm): -5.22. LC-MS $\left(\mathrm{ESI}^{+}\right): \mathrm{C}_{34} \mathrm{H}_{39} \mathrm{~N}_{2} \mathrm{O}_{4} \mathrm{P}^{2+}$ calcd. 570.2636, found $[\mathrm{M}-\mathrm{H}]^{+}: 569.2564$.

\subsection{Cell culture and fluorescence imaging}

All tested cells were purchased from Chinese Academy of Sciences stem cell bank/stem cell technology platform. All cells were cultured at $37^{\circ} \mathrm{C}$ in $5 \% \mathrm{CO}_{2}$. Cell culture medium, such as Dulbecco's modified Eagle's medium (DMEM), RPMI (Roswell Park Memorial Institute) 1640 Medium, Minimum Essential Medium (MEM), and Fetal Bovine Serum (FBS) were purchased from Gibco (Grand Island, USA). A549 cells, HeLa cells, PC9 cells, HepG2 cells, and SMMC-7721 cells were cultured with DMEM supplemented with $10 \%$ FBS. SH-SY5Y cells, and HL-7702 cells were cultured with RPMI-1640 supplemented with 10\% FBS. HEK293 cells were cultured with MEM supplemented with 10\% FBS and 1\% L-glutamine. Fluorescent images of cells were acquired on an Olympus FluoView FV1000 laser-scanning microscope with an objective lens $(\times 60)$. Excitation wavelength at $559 \mathrm{~nm}$ and collected wavelengths were in the range of $650-750 \mathrm{~nm}$. Hoechst 33258, MitoTracker ${ }^{\circledR}$ Green FM, CellMask ${ }^{\mathrm{TM}}$ Orange Plasma Membrane stain, and ER-Tracker ${ }^{\mathrm{TM}}$ Green dye were purchased from Thermo Fisher Scientific Corporation. The co-localization parameters were analyzed by Image-Pro Plus software. 

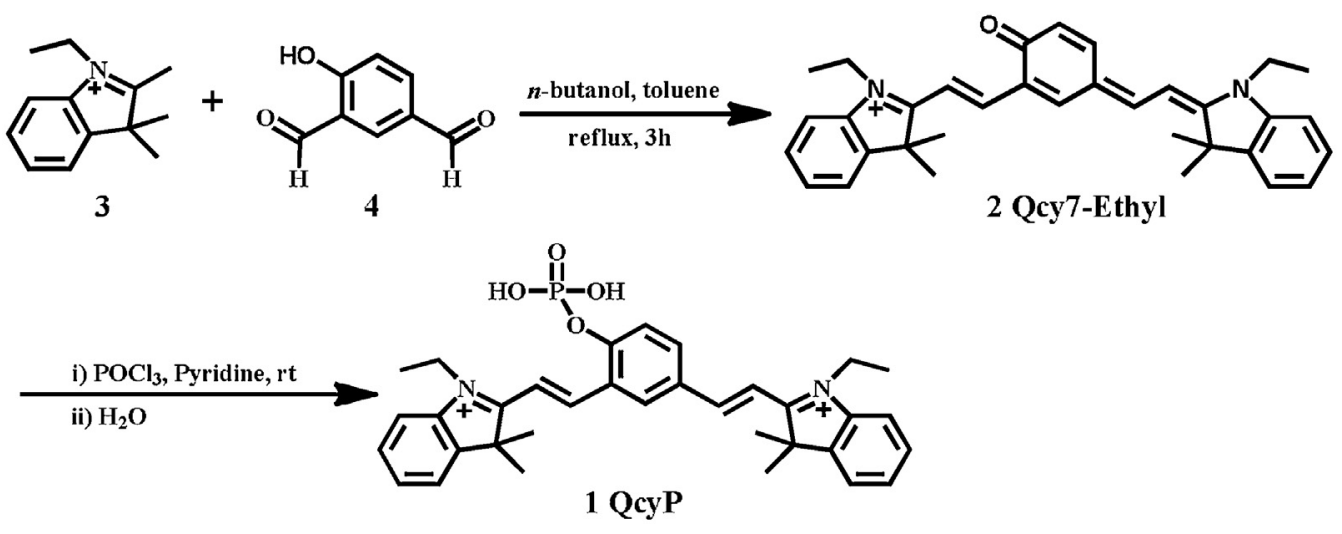

Scheme 2. Synthetic scheme of the probe QcyP.

\subsection{Flow cytometric and western blot analysis}

All tested cells were cultured at $2.0 \times 10^{5}$ cells per well in 6 -well plates and then treated with $5 \mu \mathrm{M}$ QcyP for $15 \mathrm{~min}$ at $37^{\circ} \mathrm{C}$. After incubation, cells were washed and suspended with serum - free medium. Flow cytometry data were collected by BD Biosciences FACSAria, and analyzed by Flowing Software. The flow cytometry channel was chosen as PerCP-cy 5.5.

Total proteins of various cells were extracted using a cell lysis buffer (Beyotime). Protein quantitative analysis was determined using a BCA kit (Beyotime). The electrophoretic conditions and transfer conditions were ultimately optimized for $80 \mathrm{~V}, 40 \mathrm{~min}$ and $120 \mathrm{~mA}, 2 \mathrm{~h}$, respectively. Subsequently, 5\% BSA solutions were uesd as a blocking liquid. Primary antibody ALP Monoclonal Antibody (CL1679) was incubated overnight at $4{ }^{\circ} \mathrm{C}$. Second antibody was incubated for $2 \mathrm{~h}$ at room temperature. Polyvinylidene fluoride (PVDF) membrane was exposed via using $200 \mu \mathrm{L}$ chemiluminescent solution from Super Enhancer ECL Kit (For HRP).

\subsection{Mice model and fluorescence imaging}

The mice were obtained from Binzhou Medical University. All surgical procedures were conducted in conformity with National Guidelines for the Care and Use of National Guidelines for the Care and Use of Laboratory Animals Laboratory Animals, and experimental protocols were approved by the Institutional Animal Care and Use Committee in Binzhou Medical University, Yantai, China. Approval Number: No.BZ2014-102R.

The animals had free access to standard animal feed and water in a room with temperature of $22 \pm 2{ }^{\circ} \mathrm{C}$ on a $12 \mathrm{~h}$ light-dark cycle. $\mathrm{BALB} / \mathrm{c}$ nude mice, female, 4 weeks old, and $10-15 \mathrm{~g}$, were selected. The HepG2 cells with logarithmic growth phase were cultured, digested, centrifuged, and then collected. The cell suspension with concentration of $1 \times 10^{7} / \mathrm{mL}$ was prepared by serum-free medium. The nude mice were randomly selected, and $0.2 \mathrm{~mL}$ of cell suspension was injected subcutaneously in the dorsolateral region of nude mice. After 3 weeks, the HepG2 tumor-bearing mice model was established successfully.

QcyP (1 mM DMSO) was diluted to working solution (100 $\mu \mathrm{M}$, 1:9 DMSO/saline $\mathrm{v} / \mathrm{v}$ ). Before imaging, the mice were anesthetized with a mixture of $2 \%$ isoflurane and oxygen. Fluorescence imaging was obtained from IVIS Lumina XRMS Series III In Vivo Imaging System (Perkinelmer), with an excitation filter of $580 \mathrm{~nm}$ and collected wavelengths were in the range of $650-750 \mathrm{~nm}$. Fluorescence imaging was obtained from IVIS Lumina XRMS Series III In Vivo Imaging System (Perkinelmer), with an excitation filter of $580 \mathrm{~nm}$ and collected wavelengths were in the range of $650-750 \mathrm{~nm}$.

\section{Results and discussion}

\subsection{Design strategy of QcyP for ALP detection}

Near-infrared (NIR) fluorescent probes are highly desirable owing to their deep tissue penetration, low phototoxicity, and negligible interference from biological autofluorescence. Within the family of NIR fluorophore, cyanine dyes are preferable for meeting the requirements of the in vivo bioimaging [43]. Among them, a new member heptamethine cyanine quinone derivative dye (Qcy7) exhibits high fluorescence quantum yield and good photostability [38-42]. Its NIR emission wavelength affords potential applications for the efficiency of deep bioimaging in vivo. The NIR fluorophore Qcy7-Ethyl features a turn-on detection mechanism based on a distinctive change in its $\pi$-electrons system. We envision that installation of a phosphate ester group into the phenolic hydroxyl moiety of Qcy7-Ethyl will quench the fluorescence via rearrangement of the conjugated $\pi$-electron system (Scheme 1 ). The phosphate group is a common enzyme-substrate (ES) interaction group, which has been chosen for the detection of ALP enzymatic activity []. Moreover, the incorporation of an orthofunctionalised phenyl phosphate group in the probe can increase the steric hindrance between the phosphate recognition group and the active site of phosphatase, which specially improves the selectivity against to other phosphatases, such as protein phosphatase [11]. Our new fluorescent probe QcyP is synthesized through a simple two-step procedure. The synthetic route is shown in Scheme 2. Briefly, Qcy7-Ethyl was synthesized via a retro-Knoevenagel reaction by reacting ethyl indoline (3) with resorcinol (4) in a solution of $n$-butanol: toluene $=7: 3(\mathrm{v} / \mathrm{v})$. The reaction system reflexed for $3 \mathrm{~h}$. The probe QcyP (1) was obtained via phosphorylation of Qcy7-Ethyl (2) with phosphorus oxychloride in a solvent of pyridine for $0.5 \mathrm{~h}$. Then added water and stirred for $0.5 \mathrm{~h}$. The mixture was extracted with $\mathrm{CH}_{2} \mathrm{Cl}_{2}$. The aqueous phase was concentrated and purified using a $\mathrm{C}_{18}$ reversed phase column. The details of the synthetic process were presented in the experimental (Scheme 1).

\subsection{Spectral properties of probe QcyP}

The spectral properties of probe QcyP were investigated under simulate optimum physiological conditions $37^{\circ} \mathrm{C}$. Escherichia coli $A L P$ (ECAP) was selected as ALP model. The working solution was prepared as $10 \mathrm{mM}$ Tris- $\mathrm{HCl}$ buffer $(\mathrm{pH}=8.0)$ supplemented with $1 \mathrm{mM} \mathrm{MgCl} 2$. The probe QcyP exhibited almost no obvious absorption in the light region from $400 \mathrm{~nm}$ to $800 \mathrm{~nm}$. After the addition of $\operatorname{ALP}(100 \mathrm{U} / \mathrm{L})$ for $30 \mathrm{~min}$, two sharp absorption peaks centered at $475 \mathrm{~nm}$ and $575 \mathrm{~nm}$ were observed, which was the typical absorption of the fluorophore Qcy7-Ethyl (Fig. 1a) [38,39]. The process was 
accompanied by a visible change in color from yellow to cyan within min, which provided a fast detection of ALP through colorimetric method. The extinction coefficient at $575 \mathrm{~nm}$ was determined as $\varepsilon_{575 \mathrm{~nm}}=27231 \mathrm{M}^{-1} \mathrm{~cm}^{-1}$. There is negligible fluorescence of QcyP in the absence of ALP $\left(\lambda_{e x}=575 \mathrm{~nm}\right)$. Upon the addition of $\operatorname{ALP}(100 \mathrm{U} / \mathrm{L})$ for $30 \mathrm{~min}$, the probe QcyP offered a strong fluorescence emission in the NIR region with a maximum wavelength of $685 \mathrm{~nm}$ (Fig. 1b). The large Stokes shift between the excitation and the emission wavelengths $(110 \mathrm{~nm})$ would beneficial for increasing the signal-to-noise ratio during the tests $[44,45]$. The fluorescence quantum yield was determined as $\Phi=0.072$. There was no fluorescence changes of our probe QcyP at different $\mathrm{pH}$ values (Fig. S1), and QcyP had an excellent photostablity under the testing conditions (Fig. S2 and S3). These results also demonstrated the good spectral properties of probe QcyP.

\subsection{Reaction kinetics}

The kinetic study of the QcyP towards ALP was subsequently investigated. Different concentrations of QcyP $(0.5,1,2,5,10$, and $20 \mu \mathrm{M}$ ) were added into $100 \mathrm{U} / \mathrm{L}$ ALP solution. The fluorescence intensities were recorded timely at different time intervals $(0,2,4,6,8,10,15,20,25,30 \mathrm{~min})$, respectively. As shown in Fig. 1c, the enzyme-substrate (ES) interaction indicated a fast enzymatic hydrolysis. Even at a low concentration of QcyP substrate, the fluorescence signal also could reach an approximate plateau within $20 \mathrm{~min}$. As illustrated in Fig. 1d, the reaction rate accelerated as the concentration of QcyP increased, suggesting that the activity of enzyme was the rate-limiting factor. We selected the fluorescence intensities at $2 \mathrm{~min}$ as the basis for the initial velocity of the reaction. The fitted Lineweaver-Burke equation $1 / \mathrm{V}_{0}=K_{\mathrm{M}} / V_{\max }[\mathrm{S}]+1 / V_{\max }$ are shown in Fig. 1e. The linear fitting equation was $1 / \mathrm{V}_{0}\left(\mu \mathrm{M}^{-1} \mathrm{~min}\right)=15.79 /[\mathrm{QcyP}]+1.62, \mathrm{r}=0.9993$. The Michaelis constant $K_{\mathrm{M}}$ was calculated to be $9.75 \mu \mathrm{M}$. The result indicated that the active site of the enzyme had high binding ability with QcyP (Table S1). The turnover number $\left(k_{\text {cat }}\right)$ and the catalytic efficiency constant $\left(k_{\text {cat }} / K_{M}\right)$ were then studied. $k_{\text {cat }}$ and $k_{\text {cat }} / K_{M}$ were determined to be $1.35 \mathrm{~s}^{-1}$ and $1.38 \times 10^{5} \mathrm{M}^{-1} \mathrm{~s}^{-1}$, respectively.

\subsection{Detection of ALP activity}

The concentration-dependent experiment was next carried out to evaluate the potential quantitative ability of QcyP towards ALP Activity. The dosage of $10 \mu \mathrm{M}$ QcyP was depended on $K_{\mathrm{M}}$ value. The concentrations of ALP solution ranged from 0 to $400 \mathrm{U} / \mathrm{L}$ were evaluated in consideration of the typical range of ALP in biological samples (40-150U/L) [5,46]. $10 \mu \mathrm{M}$ QcyP reacted with various dosages of ALP $(0-400 \mathrm{U} / \mathrm{L})$. After incubated for $5 \mathrm{~min}$, the fluorescence intensities were recorded (Fig. 1f). There was a good linear correlation between ALP concentrations and fluorescence intensities (Fig. 1g). The linear fitting equation was $F_{684 \mathrm{~nm}}=1214.4$ [ALP]-606.1 (U/L) with a linear fitting constant $r=0.9900$. The detection limit was calculated to be $1.0 \mathrm{U} / \mathrm{L}$ based on $3 \sigma / \mathrm{K}$. Besides, we prolonged the reaction time to $30 \mathrm{~min}$. Within the ALP activity range of $0-120 \mathrm{U} / \mathrm{L}$, there was a linear relationship between fluorescence intensity and enzyme activity (Fig. S4). The linear fitting equation was $\mathrm{F}_{685} \mathrm{~nm}=4052.2[\mathrm{ALP}]+9367(\mathrm{U} / \mathrm{L})$ with a linear fitting constant $r=0.9921$. And the limit of detection was calculated to be $0.31 \mathrm{U} / \mathrm{L}$. The detection limit of QcyP was excellent and adequately met the detection of ALP in biological samples (Table S1).

\subsection{Selectivity and enzyme inhibitor assays}

Selectivity was an important criterion to assess the suitability of the probe for biological application. The interference of our probe was investigated in the presence of various potential species. As shown in Fig. $1 \mathrm{~h}$ and S5, the probe QcyP had no response towards ions including $\mathrm{Na}^{+}, \mathrm{K}^{+}, \mathrm{Ca}^{2+}, \mathrm{Mg}^{2+}, \mathrm{Fe}^{3+}, \mathrm{Zn}^{2+}$, and $\mathrm{Cu}^{2+}$. The analogous functional enzymes (acid phosphatase and phosphodiesterase) and proteins (lysozyme, esterase, BSA, avidin, and trypsin) also could not cause any interference in working solution. But in $10 \mathrm{mM}$ Citric acid - sodium hydroxide - hydrochloric acid buffer ( $\mathrm{pH}=5.0)$, QcyP has a strong response to ACP even more than ALP (Fig. S6). However, under the alkaline conditions, ACP was almost completely inactivated and resulted in a failure of catalysis. Even under normal physiological conditions $(\mathrm{pH}=7.4)$, the acitvity of ACP stay low level in cells and in vivo. The results affirmed that QcyP possessed outstanding specificity for the detection of ALP in complex biological systems. We further performed an inhibition experiment to confirm the selective reaction between our probe QcyP and ALP. The activity of ALP was inhibited by sodium orthovanadate $\left(\mathrm{Na}_{3} \mathrm{VO}_{4}\right)$, a common phosphatases inhibitor. $100 \mathrm{U} / \mathrm{L}$ ALP was preincubated with different concentrations $(0.01,0.05$, $0.1,0.5,1,2.5,5,10,25,50,100,500,1000$, and $2000 \mu \mathrm{M})$ of inhibitor for $30 \mathrm{~min} .5 \mu \mathrm{M}$ QcyP was then added. After incubated for another $30 \mathrm{~min}$, the fluorescence intensities were recorded. Then the intensities were plotted as a function of natural logarithm of the concentrations of $\mathrm{Na}_{3} \mathrm{VO}_{4}$. As displayed in Fig. $1 \mathrm{i}$, the fluorescence intensity was gradually decreased when the concentrations of inhibitor increased. The typical sigmoidal dose-response curve well described the relationship between enzyme activity and the concentration of inhibitor. The $\mathrm{IC}_{50}$ for $\mathrm{Na}_{3} \mathrm{VO}_{4}$ was determined to be $6.73 \mu \mathrm{M}$, which is consistent with previous reported data [28]. These results affirmed that the fluorescence increase was due to the enzymatic reaction between our probe and ALP. Meanwhile, the probe QcyP could be potentially used to screening assay of ALP inhibitors.

\subsection{Imaging of ALP in HepG2 cells}

Since QcyP showed strong ability to detect ALP activity under simulated physiological conditions, we next assessed whether QcyP could detect ALP activity at physiologically relevant levels in living cells. Prior to the use of the probe for biological imaging, its biocompatibility was first tested via the CCK-8 kit assay. HepG2 cell $(200 \mu \mathrm{L})$ was plated into 96-well microtiter plates and adherently generated for $24 \mathrm{~h}$ in the incubator. The different concentrations of $\operatorname{QcyP}(0,2,5,10,20,30,40 \mu \mathrm{M})$ were added into the plates and incubated for another $24 \mathrm{~h}$. Afterwards, $10 \mu \mathrm{L}$ CCK-8 solution was added to each well. After $2 \mathrm{~h}$, absorbance at $450 \mathrm{~nm}$ was measured in a TECAN infinite M200pro microplate reader. As shown in Fig. S7, the HepG 2 cells still remained more than $90 \%$ viability under the incubation of $40 \mu \mathrm{M}$ QcyP. The result indicated that our probe QcyP had low cytotoxicity under the testing conditions. HepG2 cells were selected as test models for detecting the activity of endogenous ALP due to its high expression of ALP. As displayed in Fig. 2, the cells were divided into two groups. Before imaging, all the cells were washed three times with saline to remove the excessive probe. For group 1: HepG2 cells were incubated with $2 \mu \mathrm{M}$ QcyP for $10 \mathrm{~min}$ at $37^{\circ} \mathrm{C}$. There observed a pretty strong intracellular fluorescence (Fig. 2a). The cells in group 2 were pretreated with $1 \mathrm{mM} \mathrm{Na} \mathrm{VO}_{4}$ for $30 \mathrm{~min}$, the cells were incubated with $2 \mu \mathrm{M}$ QcyP for $10 \mathrm{~min}$. There was almost no fluorescence signal obtained. The result indicated that the activity of endogenous ALP had been competitively inhibited by $\mathrm{Na}_{3} \mathrm{VO}_{4}$. Flow cytometry analysis was utilized to further confirm the accuracy of bioimages collected from our probe QcyP (Fig. 2b). We also used Western blotting analysis to evaluate enzyme activity. As shown in Fig. $2 \mathrm{c}$, the inhibitors $\mathrm{Na}_{3} \mathrm{VO}_{4}$ could inhibit ALP. The qualitative analysis data for fluorescence imaging, flow cytometry analysis, and western blotting analysis were provided in Fig. 2d. The results demonstrated that our probe QcyP could 

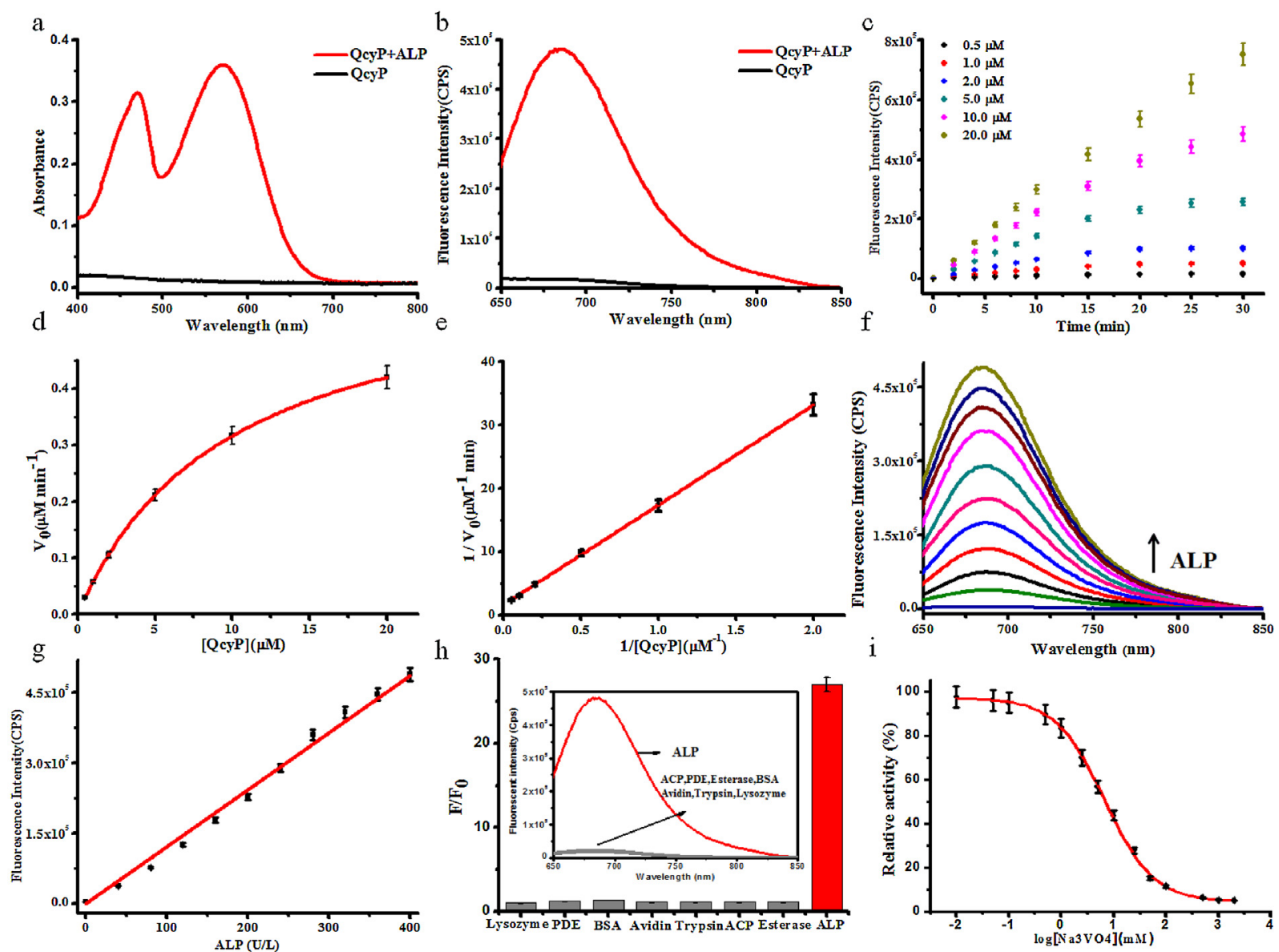

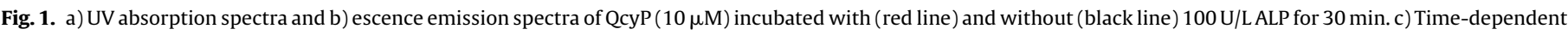

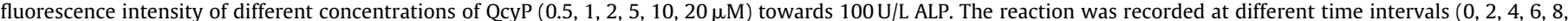

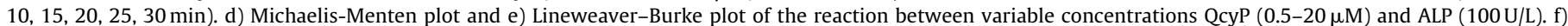

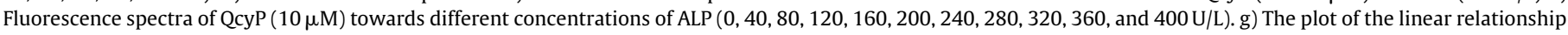

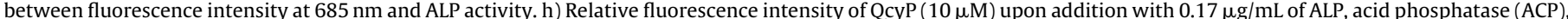

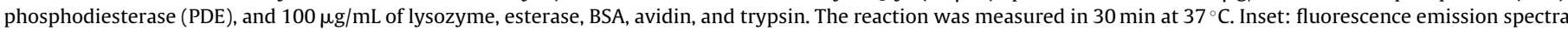

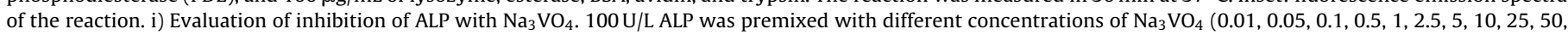

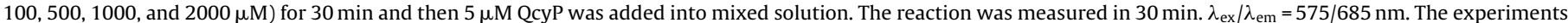

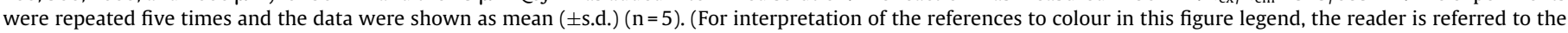
web version of this article.)

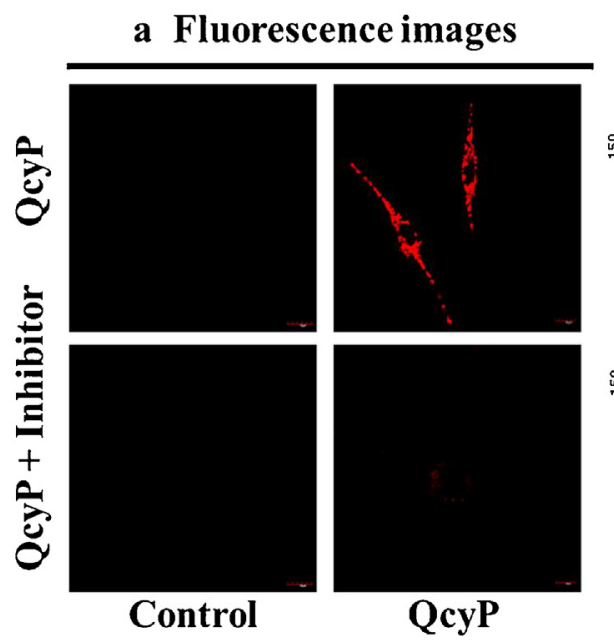

\section{b Flow cytometric analysis}

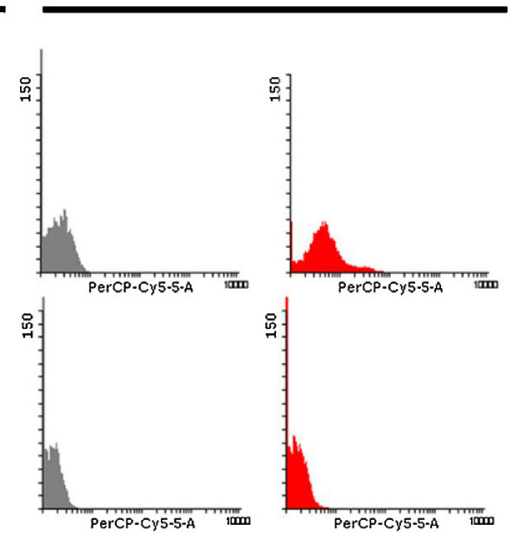

\section{c Western blot}

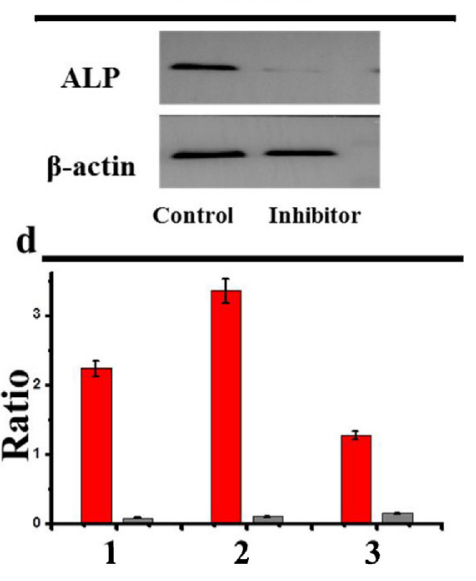

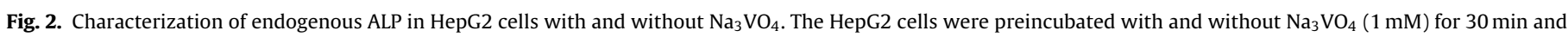

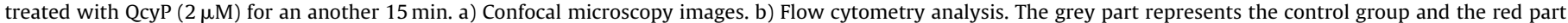

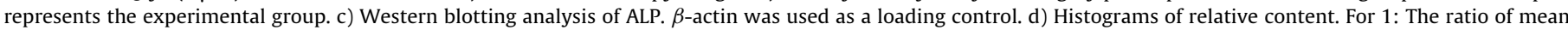

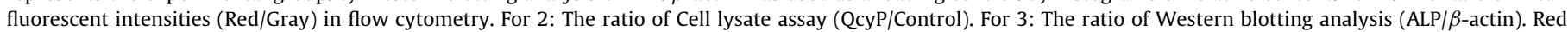

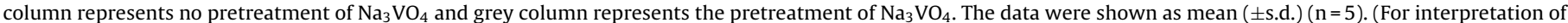
the references to colour in this figure legend, the reader is referred to the web version of this article.) 


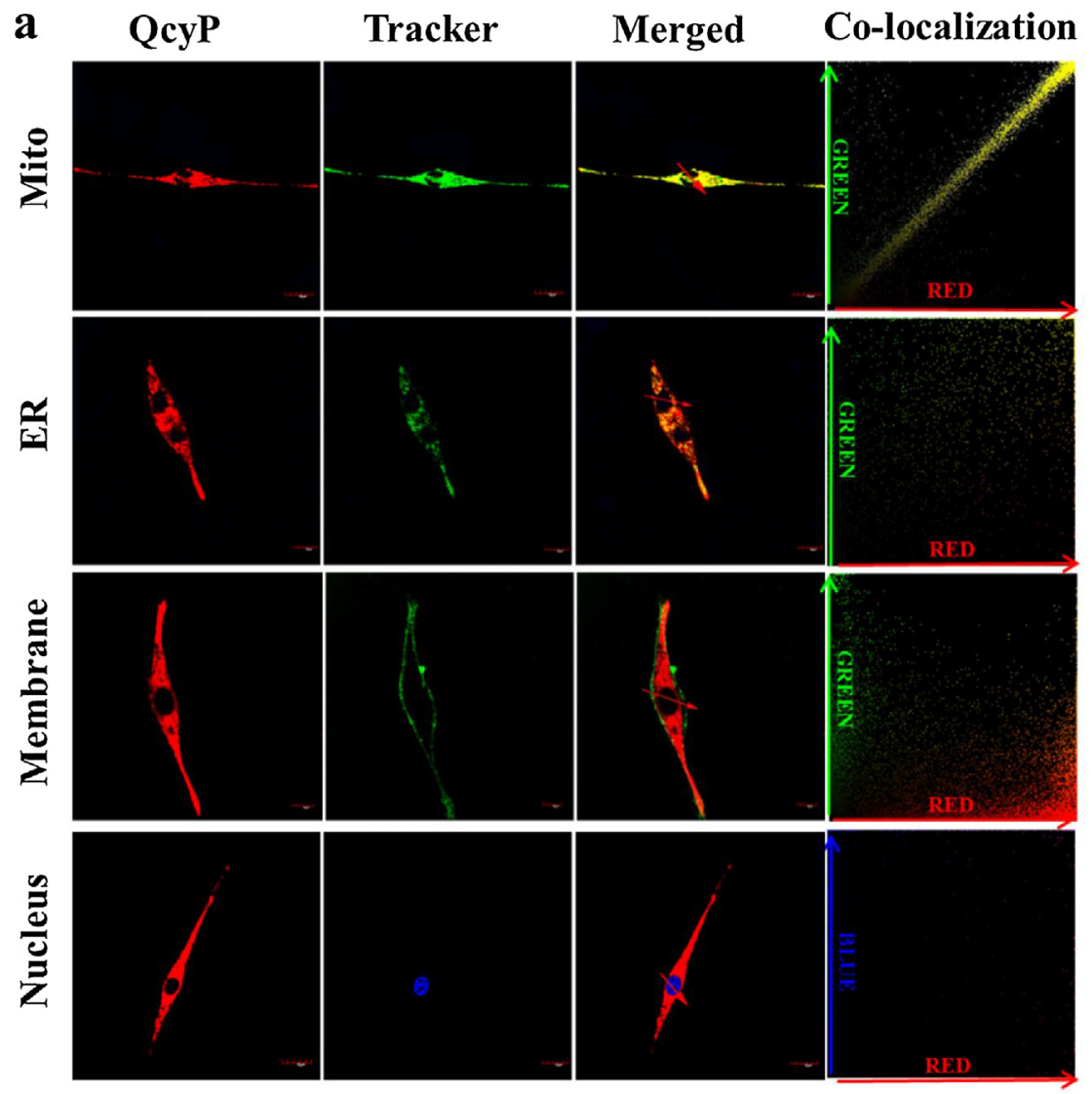

b Intensity profile
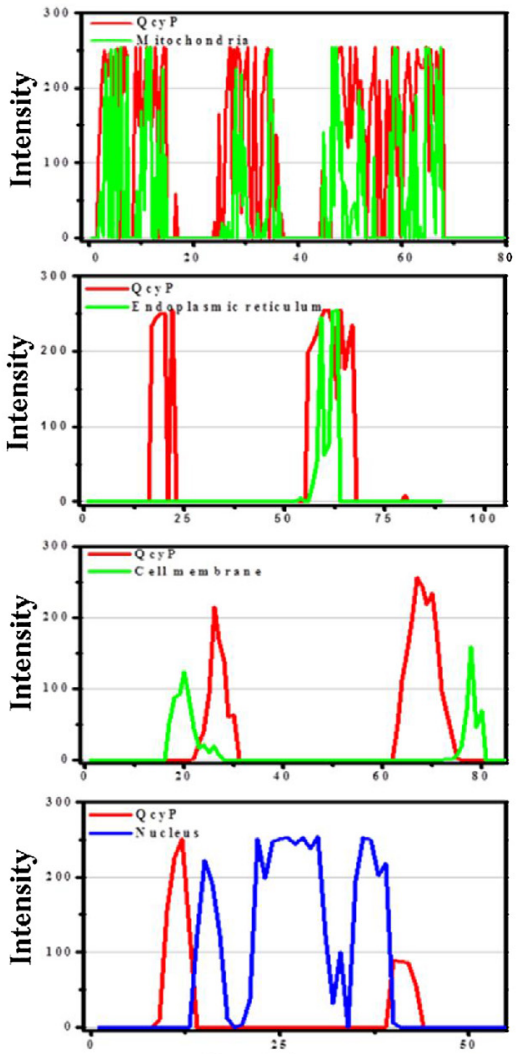

Pixel distance

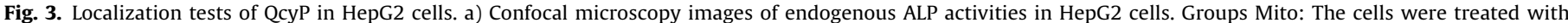

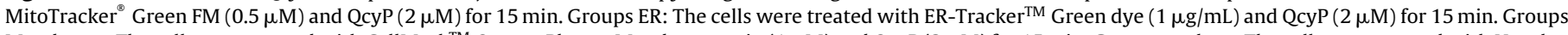

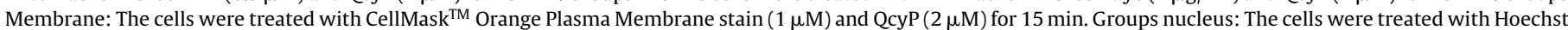

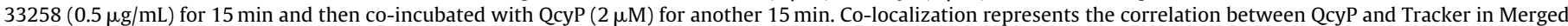

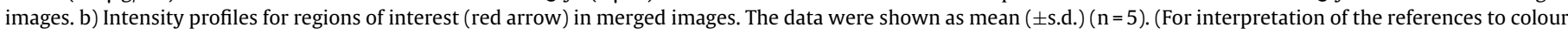
in this figure legend, the reader is referred to the web version of this article.)

be applied for the detection of endogenous ALP and its activity in cells. Subsequently, the time-course experiment of the probe was further investigated in HepG2 cells. $2 \mu \mathrm{M}$ probe QcyP was added into the cell culture dish and then the images were acquired at different time points: $30 \mathrm{~s}, 1 \mathrm{~min}, 3 \mathrm{~min}, 5 \mathrm{~min}, 10 \mathrm{~min}, 15 \mathrm{~min}$. As illustrted in Fig. S8, the intensities of fluorescence images gradually increased because of the enzymatic reaction. Furthermore, the kinetic study of the QcyP in living HepG2 cells was investigated. As shown in Fig. S9, the fitted Lineweaver-Burke equation was $1 / \mathrm{V}_{0}\left(\mu \mathrm{M}^{-1} \mathrm{~min}\right)=139.25 /[\mathrm{QcyP}]+8.73, \mathrm{r}=0.9909$. The Michaelis constant $K_{\mathrm{M}}$ was calculated to be $15.95 \mu \mathrm{M}$. All the results demonstrated that our probe had potential to detect endogenous ALP in cells.

\subsection{Subcellular colocalization in cells}

The distribution of ALP in the cell is very extensive from the cell membrane to the cytoplasm (endoplasmic reticulum, mitochondria), and even to the nucleus [12,47]. In order to investigate the intracellular distribution of the probe, organelle co-localization assay was carried out. The commercial dyes which selectively stained mitochondria, endoplasmic reticulum, cell membrane, and nucleus were used to trace the distribution of the probe QcyP in cells. As shown in Fig. 3, all the HepG2 cells were incubated with the probe QcyP $(2 \mu \mathrm{M}) 10 \mathrm{~min}$ at $37^{\circ} \mathrm{C}$. The fluorescent image was construct from fluorescence collection window: 650-750 nm, with excitation wavelength $\left(\lambda_{\text {ex }}\right)$ at $559 \mathrm{~nm}$. And the optimum operation conditions of other commercial dyes for mitochondria, endoplasmic reticulum, cell membrane, and nucleus were performed as follows: the incubation time of MitoTracker ${ }^{\circledR}$ Green FM $(0.5 \mu \mathrm{M})$ was $15 \mathrm{~min}$ at $37^{\circ} \mathrm{C}$ and the fluorescence collection window was $450-550 \mathrm{~nm}\left(\lambda_{\mathrm{ex}}=488 \mathrm{~nm}\right)$; The incubation time of ER-Tracker ${ }^{\mathrm{TM}}$ Green dye $(1 \mu \mathrm{g} / \mathrm{mL})$ was $15 \mathrm{~min}$ at $37^{\circ} \mathrm{C}$ and the fluorescence collection window was $450-550 \mathrm{~nm}\left(\lambda_{\mathrm{ex}}=488 \mathrm{~nm}\right)$; CellMask ${ }^{\mathrm{TM}}$ Orange Plasma Membrane stain $(1 \mu \mathrm{M})$ was added into Petri-dishes for $15 \mathrm{~min}$ at $37^{\circ} \mathrm{C}$ and the fluorescence collection window set from 510 to $610 \mathrm{~nm}\left(\lambda_{\mathrm{ex}}=559 \mathrm{~nm}\right)$. Hoechst $33258(0.5 \mu \mathrm{g} / \mathrm{mL})$ was added into Petri-dish for $30 \mathrm{~min}$ at $37^{\circ} \mathrm{C}$ and with a fluorescence collection window from 410 to $510 \mathrm{~nm}\left(\lambda_{\text {ex }}=405 \mathrm{~nm}\right)$. We then performed intensity correlation analysis of the dyads between images of QcyP and images of other organelle dye, respectively. The intensities of stain color-pair for each pixel in the merged images demonstrated the intensity distribution of the two colocalization dyes. The result illustrated that our probe QcyP predominantly accumulated in mitochondria due to the mitochondria-targeting ability of the cyanine dyes. The Pearson's colocalization coefficient was calculated as $\mathrm{Rr}=0.91$, and the Manders' coefficients were determined as $\mathrm{m}_{1}=0.95, \mathrm{~m}_{2}=0.97$. The fluorescence intensity profiles of regions of interest (red arrow) in merged images exhibited to be highly synchronous. All the results indicated that our probe QcyP could locate in mitochondria and respond to ALP in mitochondria. 


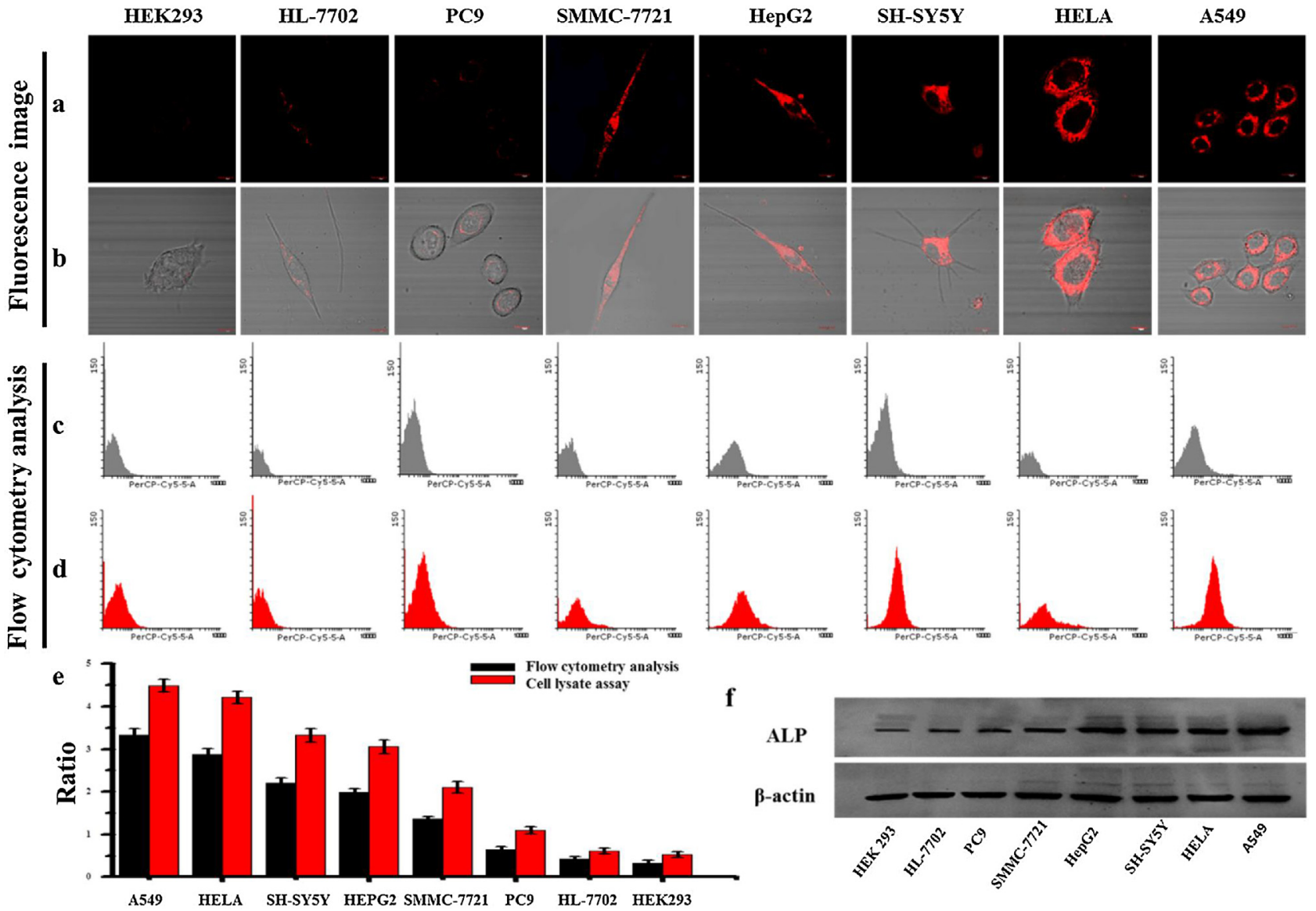

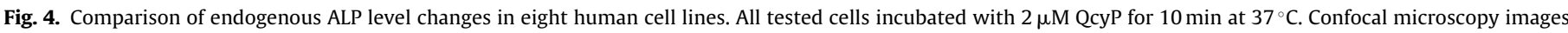

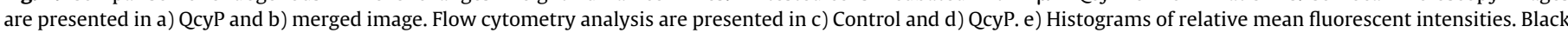

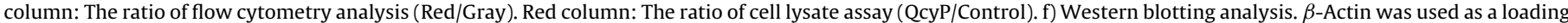

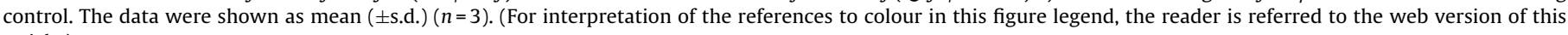
article.)

\subsection{Quantification of ALP levels in different cell lines}

Since the probe QcyP provided a simple and rapid chemical tool for selectively detecting endogenous ALP activity in live cells, we next investigated whether it could be used to quantify the levels of ALP in different cell lines. We selected eight cell lines form different organs to evaluate capability of the probe for ALP detection. As displayed in Fig. 4, the total of eight human cell lines were HEK293 cell line, HL-7702 cell line, PC9 cell line, A549 cell line, SMMC7721 cell line, SH-SY5Y cell line, HepG2 cell line, and HeLa cell line. All cell lines were incubated with $2 \mu \mathrm{M}$ QcyP for $10 \mathrm{~min}$ at $37^{\circ} \mathrm{C}$. Before observed images using confocal microscope, the cells were washed with saline for three times. As shown in Fig. 4a and $4 \mathrm{~b}$, there are differences in the fluorescence image intensities of the eight cell lines. A549 cell line and HeLa cell line emitted strong fluorescence, respectively. SH-SY5Y cell line, HepG2 cell line and SMMC-7721 cell line provided medium fluorescence images. PC9 cell line, HL-7702 cell line, and HEK293 cell line offered weak fluorescence images. Flow cytometry analysis was performed to verify the above results. The results (Fig. $4 \mathrm{c}$ and $4 \mathrm{~d}$ ) were consisted with the confocal microscopy images results in Fig. $4 \mathrm{a}$ and $4 \mathrm{~b}$. Interestingly, although the PC9 and A549 cell lines were all derived from lung adenocarcinoma cell lines, the enzyme level and activity indicated the difference in maturation [48]. Similarly, liver cancer cell lines (HepG2 and SMMC-7721) expressed different levels of ALP. However, human normal HL-7702 cells preserved relatively low level of ALP in comparison with cancer cells, because ALP was overexpressed in cancer cells. The levels of ALP expression were further assessed via Western blot analysis (Fig. 4f and S12). The results were high consistent with the result of fluorescence imaging analysis. But one should note that the high level and activity of ALP were not considered as a diagnostic indicator for a specific diseases. Flow cytometric analysis and cell lysate assay were performed to further quantify levels of ALP in these cell lines (Fig. 4e). According to the standard curves of QcyP (Fig. 1g), the ALP activity was estimated to be $10.15 \pm 0.38 \mathrm{U} / \mathrm{L}$ and $9.58 \pm 0.35 \mathrm{U} / \mathrm{L}$ in $\mathrm{A} 549$ and HeLa cells, respectively. And in medium fluorescence group, the ALP activity was determined to be $7.04 \pm 0.36 \mathrm{U} / \mathrm{L}, 6.86 \pm 0.33 \mathrm{U} / \mathrm{L}$, and $4.72 \pm 0.28 \mathrm{U} / \mathrm{L}$ in SH-SY5Y cells, HepG2 cells, and SMMC-7721 cells, respectively. The ALP activity of PC9 cells, HL-7702 cells, and HEK293 cells was evaluated to be $2.48 \pm 0.21 \mathrm{U} / \mathrm{L}, 1.37 \pm 0.22 \mathrm{U} / \mathrm{L}$, and $1.19 \pm 0.18 \mathrm{U} / \mathrm{L}$, respectively.

\subsection{In vivo imaging in mice}

Near-infrared (NIR) fluorescence probe can effectively provide high imaging resolution and sensitivity with increasing tissue penetration depths, owing to advances in reducing photon scattering, hemoglobin absorption and auto-fluorescence [37]. We further evaluated the suitability of QcyP for bioimaging ALP level and activity in vivo. Clinical manifestations indicate that the liver cancer is often associated with elevated ALP level in serum [3]. The HepG2 tumor-bearing mice model was constructed because of the high level of ALP in the tumor region and the blood [49]. As shown in Fig. 5, the BALB/c nude mice were divided into three groups for imaging of ALP in vivo. The nude mice in group a were intraperi- 

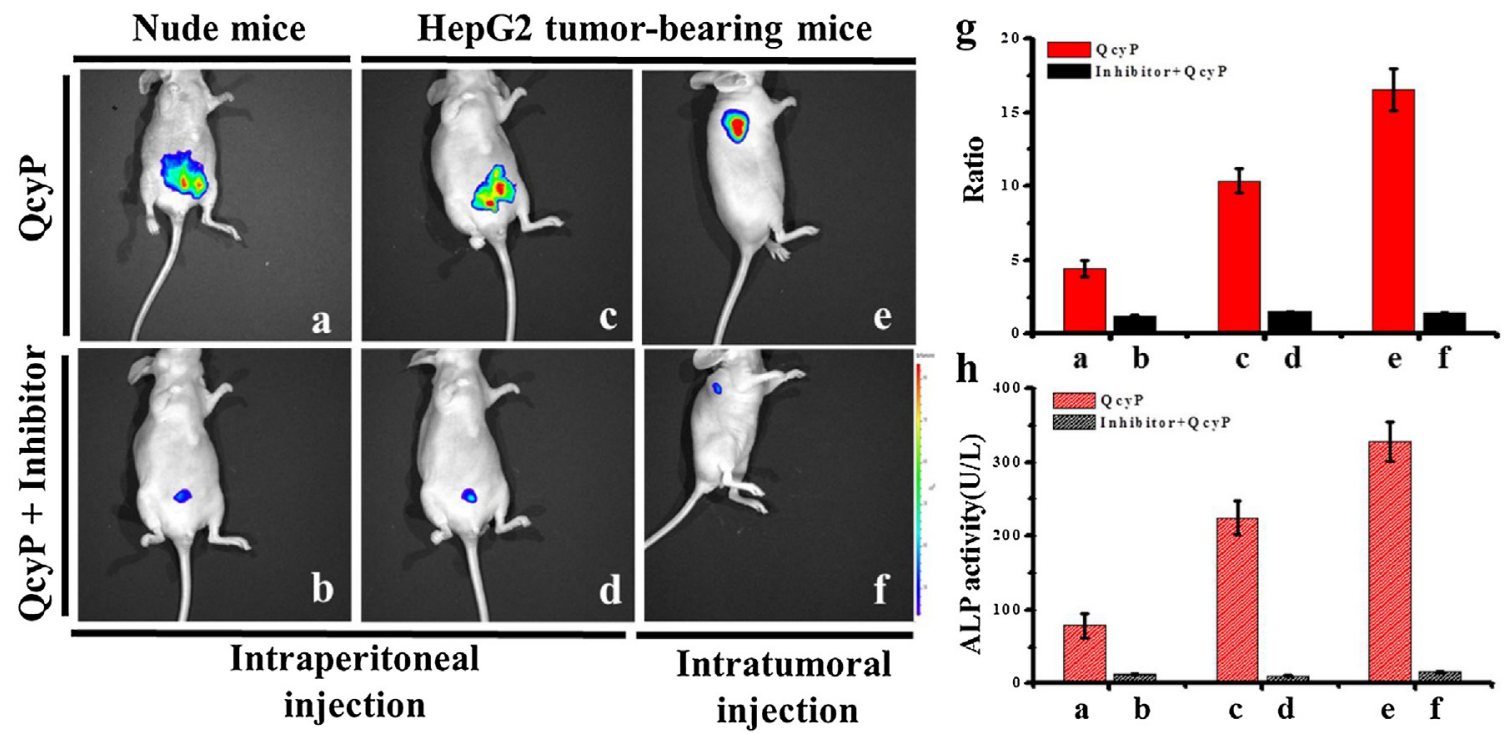

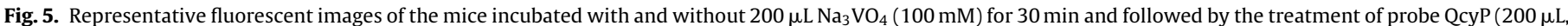

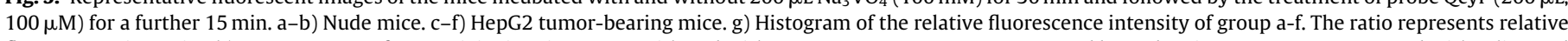

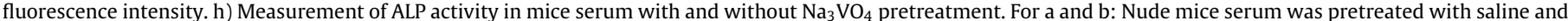

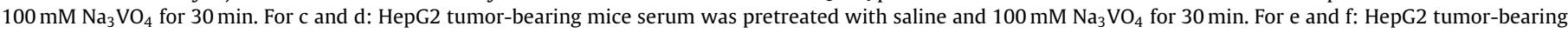

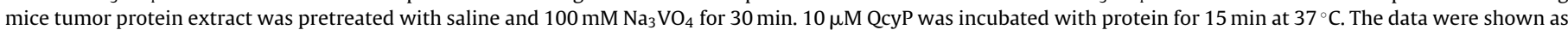
mean $( \pm$ s.d. $)(n=3)$.

toneally injected a dosage of $200 \mu \mathrm{L}$ probe QcyP $(100 \mu \mathrm{M}, 1: 9$ DMSO/saline v/v) for $30 \mathrm{~min}$ (Fig. 5a). The HepG2 tumor-bearing nude mice in group b were given intratumoral injection of $200 \mu \mathrm{L}$ probe QcyP (100 $\mu \mathrm{M}, 1: 9 \mathrm{DMSO} /$ saline $\mathrm{v} / \mathrm{v}$ ) for $30 \mathrm{~min}$ (Fig. $5 \mathrm{~b}$ ). The tumor-bearing nude mice in group $\mathrm{c}$ were given intraperitoneal (i.p.) injection of a dosage of $200 \mu \mathrm{L}$ probe QcyP $(100 \mu \mathrm{M}$, 1:9 DMSO/saline v/v) for $30 \mathrm{~min}$ (Fig. 5d). Each group was set an inhibitor group, respectively. After pretreated by a i.p. injection of $200 \mu \mathrm{L}$ of $\mathrm{Na}_{3} \mathrm{VO}_{4}(100 \mathrm{mM}$ in saline) for $30 \mathrm{~min}$, the nude mice in Fig. 5b were then treated as described in group a. The tumorbearing nude mice in Fig. 5b were intratumorally injected $200 \mu \mathrm{L}$ of $\mathrm{Na}_{3} \mathrm{VO}_{4}(100 \mathrm{mM}$ in saline $)$ for $30 \mathrm{~min}$, then treated as described in Fig. 5c. The tumor-bearing nude mice in Fig. $5 \mathrm{f}$ were afforded i.p. injection of $200 \mu \mathrm{L}$ of $\mathrm{Na}_{3} \mathrm{VO}_{4}$ ( $100 \mathrm{mM}$ in saline) for $30 \mathrm{~min}$, then treated as described in Fig. 5e. The mice were finally anesthetized by isoflurane for in vivo imaging. The fluorescence imaging was obtained from IVIS Lumina XRMS Series III In Vivo Imaging System (Perkinelmer), with collected window $650-750 \mathrm{~nm}\left(\lambda_{\mathrm{ex}}=580 \mathrm{~nm}\right)$. As shown in Fig. $5 \mathrm{~b}$, the tumor region of tumor bearing mice provided strong fluorescence signal, which indicated the high level of ALP in the lesion of HepG2 cancer model. The $\mathrm{Na}_{3} \mathrm{VO}_{4}$ pretreatment could lead to an obvious 9-fold decrease in fluorescence intensity (Fig. 5b). As known, the level of ALP in human serum is used to help diagnosis by physician as a biomarker. The i.p. injection test revealed a high ALP level in the tumor-bearing nude mice (Fig. 5d). In normal nude mice, the level and activity of ALP was lower than that of tumor-bearing mice. The fluorescence intensity in abdominal cavity was 2.3-fold lower than that of HepG2 tumor-bearing mice (Fig. 5g). And the inhibitor experiment in vivo could result in weak fluorescence emission (Fig. 5b, d, f). The result verified that the
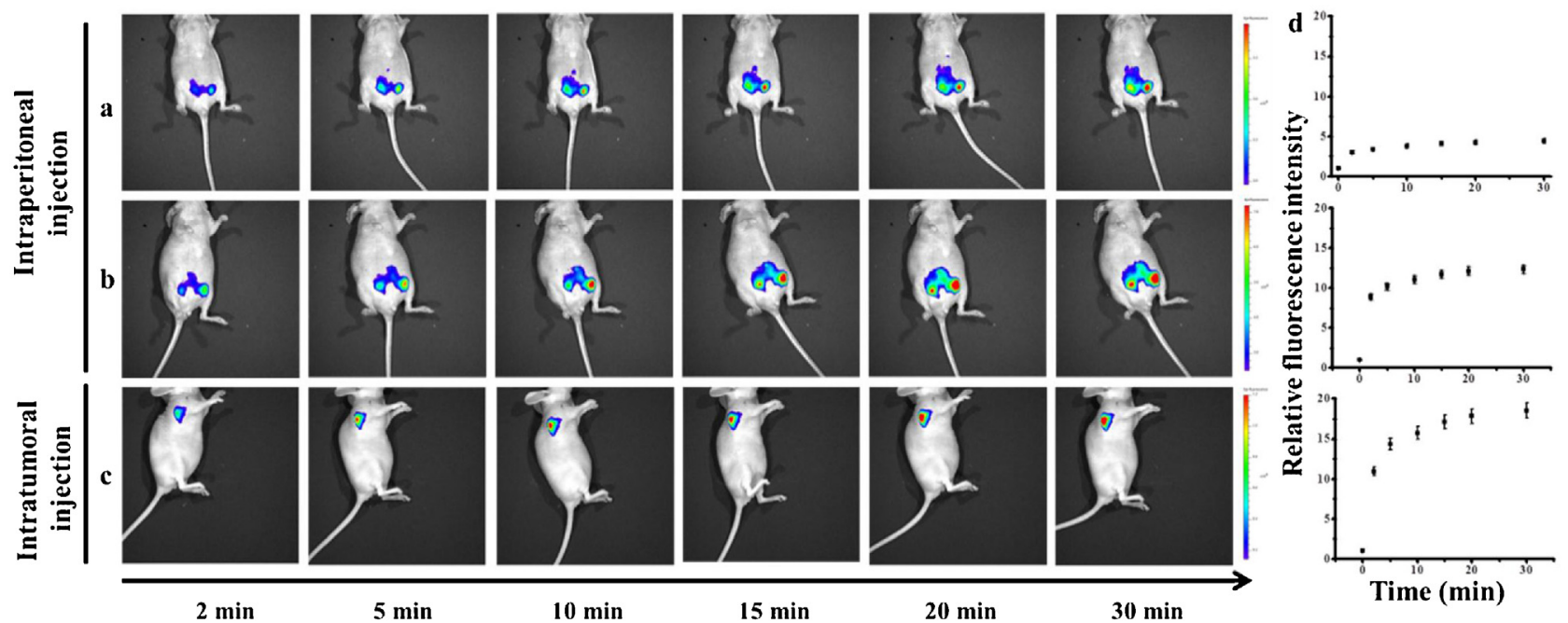

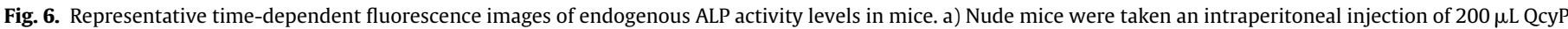

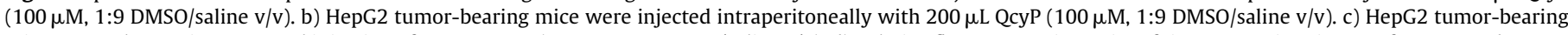

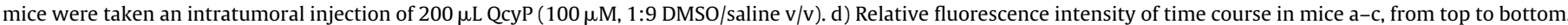


fluorescence emission initiated from the enzymatic hydrolysis of the ALP. The levels of ALP in serum were also assessed (Fig. 5h). The results were consistent well with imaging analysis. According to the standard curves of QcyP (Fig. 1g), the activity of ALP in mice serum were $78.81 \pm 16.92 \mathrm{U} / \mathrm{L}$ in normal mice, and $224.08 \pm 22.63 \mathrm{U} / \mathrm{L}$ in tumor-bearing mice. The activity of ALP in mice tumor protein extract was $327.86 \pm 27.06 \mathrm{U} / \mathrm{L}$. The inhibitor $\mathrm{Na}_{3} \mathrm{VO}_{4}$ was added to the serum $30 \mathrm{~min}$ later, the activity of ALP in mice serum were determined to be $10.51 \pm 0.54 \mathrm{U} / \mathrm{L}$ and $15.93 \pm 0.67 \mathrm{U} / \mathrm{L}$ in normal mice, and tumor-bearing mice, respectively. The activity of ALP in mice tumor protein extract was evaluated to be $15.93 \pm 0.85 \mathrm{U} / \mathrm{L}$.

We then employed the probe to conduct the time-course dependent experiment. The assays were performed with three groups of mice. The mice in Fig. 6a were intraperitoneally injected with $200 \mu \mathrm{L}$ probe QcyP $(100 \mu \mathrm{M}, 1: 9 \mathrm{DMSO} /$ saline $\mathrm{v} / \mathrm{v})$. The tumorbearing mice in Fig. 6b were given an intratumoral injection with $200 \mu \mathrm{L}$ probe QcyP $(100 \mu \mathrm{M}, 1: 9 \mathrm{DMSO} /$ saline $\mathrm{v} / \mathrm{v})$. The tumorbearing mice in Fig. $6 \mathrm{c}$ were afforded an intraperitoneal injection with $200 \mu \mathrm{L}$ probe QcyP $(100 \mu \mathrm{M}, 1: 9 \mathrm{DMSO} / \mathrm{saline} \mathrm{v} / \mathrm{v})$. The dynamic changes of fluorescence intensities were immediately monitored using In Vivo Imaging System. All fluorescence intensities increased along with time. But the rate and fluorescence intensity were different. The fluorescence intensity of the whole tumor region rapidly increased with $5 \mathrm{~min}$, which was attributed to the catalytic hydrolysis of our probe QcyP by the tumor-generated ALP. The fluorescence intensity of tumor-bearing mice were significantly higher than that of in the normal mice. The result indicated that HepG2 derived tumor could elevate the concentration of ALP in mice. Kinetic changes in fluorescence signals were plotted in Fig. $6 \mathrm{~d}$. The result also demonstrated that our probe could act as a good chemical tool for imaging level changes of ALP in vivo in realtime. The fluorescence changes in the above five operations were also offered as videos (Videos: I-III in Supplementary information).

\section{Conclusion}

In summary, we have designed and synthesized a NIR fluorescence probe QcyP for imaging and evaluating endogenous ALP changes in different cell lines and in tumor-bearing mice models. Our probe consists of two parts: a unique heptamethine cyanine as the fluorescence modulator and a phosphate monoester as the response moiety for ALP enzymatic reactions. The probe QcyP effectively exhibits an off-on fluorescence increase signal in response to ALP via the enzyme-catalyzed cleavage of the phosphate group. QcyP can selectively and sensitively respond to ALP without interferences of other enzymes, ions, and proteins. The subcellular distribution of QcyP in HepG2 cells has been identified in mitochondria. The probe has also been used to evaluate the different levels of ALP in eight human cell lines, revealing that the cancer cell lines have high-level expression of ALP. Moreover, the probe can be used to distinguish the ALP level difference between HepG2 tumor-bearing mice model and normal mice. The above applications make our probe a potential candidate for revealing the roles of ALP in physiological and pathological processes.

\section{Acknowledgements}

We thank the National Nature Science Foundation of China (No. 41506126, No. 21775162, No. 41776110, and No. 21575159), the program of Youth Innovation Promotion Association, CAS (Grant 2015170), State Key Laboratory of Environmental Chemistry and Ecotoxicology, Research Center for Eco-Environmental Sciences, CAS (Grant KF2016-22), and Key Laboratory of Sensor Analysis of Tumor Marker Ministry of Education, Qingdao University of Science and Technology (Grant SATM201705).

\section{Appendix A. Supplementary data}

Supplementary data associated with this article can be found, in the online version, at https://doi.org/10.1016/j.snb.2018.03.078.

\section{References}

[1] J.E. Coleman, Structure and mechanism of alkaline phosphatase, Annu. Rev. Biophys. (1992) 441-483.

[2] J.L. Millán, Alkaline phosphatases, Purinergic Signal. 2 (2006) 335-341.

[3] V.O. Van Hoof, M.E. De Broe, Interpretation and clinical significance of alkaline phosphatase isoenzyme patterns, Crit. Rev. Clin. Lab. Sci. 31 (1994) 197-293.

[4] (a) C.H.S. Lu, K. Liu, L.P. Tan, S.Q. Yao, Current chemical biology tools for studying protein phosphorylation and dephosphorylation, Chem. A: Eur. J. 18 (2012) 28-39;

(b) N.S. Fedarko, P. Bianco, U. Vetter, P. Gehron Robey, Human bone cell enzyme expression and cellular heterogeneity: correlation of alkaline phosphatase enzyme activity with cell cycle, J. Cell. Physiol. 114 (1990) 115-121.

[5] (a) B.A. Rader, Alkaline phosphatase, an unconventional immune protein, Front. Immunol. 8 (2017) 897;

(b) H. Harris, The human alkaline phosphatases: what we know and what we don't know, Clin. Chim. Acta 186 (1990) 133-150.

[6] H. Chen, C. Wang, X. Yang, Z. Xiao, X. Zhu, K. Zhang, Y. Fan, X. Zhang, Construction of surface $\mathrm{HA} / \mathrm{TiO} 2$ coating on porous titanium scaffolds and its preliminary biological evaluation, Mater. Sci. Eng. C 70 (2017) 1047-1056.

[7] B. Gomez, S. Ardakani, J. Ju, D. Jenkins, M.J. Cerelli, G.Y. Daniloff, V.T. Kung, Monoclonal antibody assay for measuring bone-specific alkaline phosphatase activity in serum, Clin. Chem. 41 (1995) 1560-1566.

[8] C. Shen, X. Li, A. Rasooly, L. Guo, K. Zhang, M. Yang, A single electrochemical biosensor for detecting the activity and inhibition of both protein kinase and alkaline phosphatase based on phosphate ions induced deposition of redox precipitates, Biosens. Bioelectron. 85 (2016) 220-225.

[9] H. Sun, C.H.S. Lu, M. Uttamchandani, Y. Xia, Y.C. Liou, S.Q. Yao, Peptide microarray for high-throughput determination of phosphatase specificity and biology, Angew. Chem. Int. Ed. 47 (2008) 1698-1702.

[10] S.J. Li, C.Y. Li, Y.F. Li, J. Fei, P. Wu, B. Yang, J. Ou-Yang, S.-X. Nie, Facile and sensitive near-Infrared fluorescence probe for the detection of endogenous alkaline phosphatase activity In vivo, Anal. Chem. 89 (2017) 6854-6860.

[11] H. Zhang, P. Xiao, Y.T. Wong, W. Shen, M. Chhabra, R. Peltier, Y. Jiang, Y. He, J He, Y. Tan, Y. Xie, D. Ho, Y.W. Lam, J. Sun, H. Sun, Construction of an alkaline phosphatase-specific two-photon probe and its imaging application in living cells and tissues, Biomaterials 140 (2017) 220-229.

[12] H.W. Liu, K. Li, X.X. Hu, L. Zhu, Q. Rong, Y. Liu, X.B. Zhang, J. Hasserodt, F.L. Qu, W. Tan, In situ localization of enzyme activity in live cells by a molecular probe releasing a precipitating fluorochrome, Angew. Chem. Int. Ed. 56 (2017) $11788-11792$

[13] Y. Tan, L. Zhang, K.H. Man, R. Peltier, G. Chen, Reaction- based off-on near-infrared fluorescent probe for imaging alkaline phosphatase activity in living cells and mice, ACS Appl. Mater. Interfaces 9 (2017) 6796-6803.

[14] X. Hu, X. Wu, X. Fang, Z. Li, G. Wang, Switchable fluorescence of gold nanoclusters for probing the activity of alkaline phosphatase and its application in immunoassay, Biosens. Bioelectron. 77 (2016) 666-672.

[15] H. Huang, B. Wang, M. Chen, M. Liu, Y. Leng, X. Liu, Y. Li, Z. Liu, Fluorescence turn-on sensing of ascorbic acid and alkaline phosphatase activity based on graphene quantum dots, Sens. Actuators B: Chem. 235 (2016) 356-361.

[16] J. OuYang, C.Y. Li, Y.F. Li, B. Yang, S.J. Li, An infinite coordination polymer nanoparticles-based near-infrared fluorescent probe with high photostability for endogenous alkaline phosphatase in vivo, Sens. Actuators B: Chem. 255 (2018) 3355-3363.

[17] X. Fang, X.Q. Li, H. Wang, X.M. Wu, G.L. Wang, Tuning surface states to achieve the modulated fluorescence of carbon dots for probing the activity of alkaline phosphatase and immunoassay of $\alpha$-fetoprotein, Sens. Actuators B Chem. 257 (2018) 620-628.

[18] C. Ma, H. Tan, L. Chen, Y. Song, F. Xu, S. Chen, L. Wang, A terbium chelate based fluorescent assay for alkaline phosphatase in biological fluid, Sens. Actuators B: Chem. 202 (2014) 683-689.

[19] R. Freeman, T. Finder, R. Gill, I. Willner, Probing protein kinase (CK2) and alkaline phosphatase with CdSe/ZnS quantum dots, Nano Lett. 10 (2010) 2192-2196.

[20] G. Li, H. Fu, X. Chen, P. Gong, G. Chen, L. Xia, H. Wang, J. You, Y. Wu, Facile and sensitive fluorescence sensing of alkaline phosphatase activity with photoluminescent carbon dots based on inner filter effect, Anal. Chem. 88 (2016) 2720-2726

[21] O. Hu, F. Zeng, C. Yu, S. Wu, A fluorescent probe for alkaline phosphatase via excited state intramolecular proton transfer, Sens. Actuators B: Chem. 220 (2015) 720-726.

[22] J. Liu, D. Tang, Z. Chen, X. Yan, Z. Zhong, L. Kang, J. Yao, Chemical redox modulated fluorescence of nitrogen-doped graphene quantum dots for probing the activity of alkaline phosphatase, Biosens. Bioelectron. 94 (2017) $271-277$.

[23] Z. Qian, L. Chai, C. Tang, Y. Huang, J. Chen, H. Feng, Carbon quantum dots-based recyclable real-time fluorescence assay for alkaline phosphatase with adenosine triphosphate as substrate, Anal. Chem. 87 (2015) 2966-2973. 
[24] G. Li, H. Fu, X. Chen, P. Gong, G. Chen, L. Xia, H. Wang, J. You, Y. Wu, Facile and sensitive fluorescence sensing of alkaline phosphatase activity with photoluminescent carbon dots based on inner filter effect, Anal. Chem. 88 (2016) 2720-2726

[25] B.H. Li, Y.L. Zhang, F.S. Li, W. Wang, J. Liu, M. Liu, Y. Cui, X.B. Li, B.L. Li, A novel sensor for the detection of alkaline phosphatase activity based on the self-assembly of $\mathrm{Eu}^{3+}$-doped oxide nanoparticles and heptamethine cyanine dye, Sens. Actuators B: Chem. 233 (2016) 479-485.

[26] H. Huang, B. Wang, M. Chen, M. Liu, Y. Leng, X. Liu, Y. Li, Z. Liu, Fluorescence turn-on sensing of ascorbic acid and alkaline phosphatase activity based on graphene quantum dots, Sens. Actuators B. Chem. 235 (2016) 356-361.

[27] Z. Qian, L. Chai, C. Tang, Y. Huang, J. Chen, H. Feng, Carbon quantum dots-based recyclable real-time fluorescence assay for alkaline phosphatase with adenosine triphosphate as substrate, Anal. Chem. 87 (2015) 2966-2973.

[28] J. Deng, P. Yu, Y. Wang, L. Mao, Real-time ratiometric fluorescent assay for alkaline phosphatase activity with stimulus responsive infinite coordination polymer nanoparticles, Anal. Chem. 87 (2015) 3080-3086.

[29] (a) J. Chan, S.C. Dodani, C.J. Chang, Reaction-based small-molecule fluorescent probes for chemoselective bioimaging, Nat. Chem. 4 (2012) 973; (b) L. Yuan, W. Lin, K. Zheng, S. Zhu, FRET-based small-molecule fluorescent probes: rational design and bioimaging applications, Acc. Chem. Res. 46 (2013) 1462-1473;

(c) M.H. Lee, J.S. Kim, J.L. Sessler, Small molecule-based ratiometric fluorescence probes for cations, anions, and biomolecules, Chem. Soc. Rev. 44 (2015) 4185-4191;

(d) L. Yuan, W. Lin, K. Zheng, L. He, W. Huang, Far-red to near infrared analyte-responsive fluorescent probes based on organic fluorophore platforms for fluorescence imaging, Chem. Soc. Rev. 42 (2013) 622-661; (e) X. Li, X. Gao, W. Shi, H. Ma, Design strategies for water-soluble small molecular chromogenic and fluorogenic probes, Chem. Rev. 114 (2014) 590-659;

(f) X. Zhang, J. Yin, J. Yoon, Recent advances in development of chiral fluorescent and colorimetric sensors, Chem. Rev. 114 (2014) 4918-4959.

[30] J.H. Lin, Y.C. Yang, Y.C. Shih, S.Y. Hung, C.Y. Lu, W.L. Tseng, Photoinduced electron transfer between Fe(III) and adenosine triphosphate-BODIPY conjugates: application to alkaline-phosphatase-linked immunoassay, Biosens. Bioelectron. 77 (2016) 242-248.

[31] H. Zhang, C. Xu, J. Liu, X. Li, L. Guo, X. Li, An enzyme-activatable probe with a self-immolative linker for rapid and sensitive alkaline phosphatase detection and cell imaging through a cascade reaction, Chem. Commun. 51 (2015) 7031-7034.

[32] L. Dong, Q. Miao, Z. Hai, Y. Yuan, G. Liang, Enzymatic hydrogelation-induced fluorescence turn-off for sensing alkaline phosphatase in vitro and in living cells, Anal. Chem. 87 (2015) 6475-6478.

[33] Z. Song, R.T.K. Kwok, E. Zhao, Z. He, Y. Hong, J.W.Y. Lam, B. Liu, B.Z. Tang, A ratiometric fluorescent probe based on ESIPT and AIE processes for alkaline phosphatase activity assay and visualization in living cells, ACS Appl. Mater. Interfaces 6 (2014) 17245-17254.

[34] Z. Lu, J. Wu, W. Liu, G. Zhang, P. Wang, A ratiometric fluorescent probe for quantification of alkaline phosphatase in living cells, RSC Adv. 6 (2016) 32046-32051.

[35] Q. Hu, F. Zeng, C. Yu, S. Wu, A fluorescent probe for alkaline phosphatase via excited state intramolecular proton transfer, Sens. Actuators B: Chem. 220 (2015) 720-726.

[36] J.O. Escobedo, O. Rusin, S. Lim, R.M. Strongin, NIR dyes for bioimaging applications, Curr. Opin. Chem. Biol. 14 (2010) 64-70.

[37] M. Gao, F. Yu, C. Lv, J. Choo, L. Chen, Fluorescent chemical probes for accurate tumor diagnosis and targeting therapy, Chem. Soc. Rev. 46 (2017) 2237-2271.

[38] N. Karton-Lifshin, E. Segal, L. Omer, M. Portnoy, R. Satchi-Fainaro, D. Shabat, A unique paradigm for a turn-ON near-infrared cyanine-based probe: noninvasive intravital optical imaging of hydrogen peroxide, J. Am. Chem. Soc. 133 (2011) 10960-10965.

[39] N. Karton-lifshin, L. Albertazzi, M. Bendikov, P.S. Baran, D. Shabat, "Donor-Two-Acceptor" dye design: a distinct gateway to NIR fluorescence, J. Am. Chem. Soc. 134 (2012) 20412-20420.

[40] Z. Li, X. He, Z. Wang, R. Yang, W. Shi, H. Ma, In vivo imaging and detection of nitroreductase in zebra fi sh by a new near-infrared fluorescence off-on probe, Biosens. Bioelectron. 63 (2015) 112-116.

[41] A. Chevalier, Y. Zhang, O.M. Khdour, J.B. Kaye, S.M. Hecht, Mitochondrial nitroreductase activity enables selective imaging and therapeutic targeting, J. Am. Chem. Soc. 138 (2016) 12009-12012.
[42] H. Wu, S.C. Alexander, S. Jin, N.K. Devaraj, A bioorthogonal near-infrared fluorogenic probe for mRNA detection, J. Am. Chem. Soc. 138 (2016) $11429-11432$.

[43] (a) L. Yuan, W. Lin, K. Zheng, L. He, W. Huang, Far-red to near infrared analyte-responsive fluorescent probes based on organic fluorophore platforms for fluorescence imaging, Chem. Soc. Rev. 42 (2013) 622-661; (b) W. Sun, S. Guo, C. Hu, J. Fan, X. Peng, Recent development of chemosensors based on cyanine platforms, Chem. Rev. 116 (2016) 7768-7817 (c) X. Peng, F. Song, E. Lu, Y. Wang, W. Zhou, J. Fan, Y. Gao, Heptamethine cyanine dyes with a large stokes shift and strong fluorescence: a paradigm for excited-state intramolecular charge transfer, J. Am. Chem. Soc. 127 (2005) 4170-4171.

[44] X. Han, X. Song, F. Yu, L. Chen, A ratiometric near-infrared fluorescent probe for quantification and evaluation of selenocysteine-protective effects in acute inflammation, Adv. Funct. Mater. 27 (2017) 1-9.

[45] X. Han, X. Song, F. Yu, L. Chen, A ratiometric fluorescent probe for imaging and quantifying anti-apoptotic effects of GSH under temperature stress, Chem. Sci. 8 (2017) 6991-7002

[46] T.-U. Hausamen, R. Helger, W. Rick, W. Gross, Optimal conditions for the determination of serum alkaline phosphatase by a new kinetic method, Clin. Chim. Acta 15 (1967) 241-245.

[47] (a) G. Bourne, M. MacKinnon, The distribution of alkaline phosphatase in various tissues, Q. J. Exp. Physiol. Cognit. Med. Sci. 32 (1943) 1-20; (b) E.J. Krugelis, Distribution and properties of intracellular alkaline phosphatases, Biol. Bull. 90 (1946) 220-233.

[48] M.H. Kang, J. Das, S. Gurunathan, H.W. Park, H. Song, C. Park, J.H. Kim, The cytotoxic effects of dimethyl sulfoxide in mouse preimplantation embryos: a mechanistic study, Theranostics 7 (2017) 4735-4752.

[49] K.N. Khan, T. Tsutsumi, K. Nakata, K. Nakao, Y. Kato, S. Nagataki, Regulation of alkaline phosphatase gene expression in human hepatoma cells by bile acids, J. Gastroenterol. Hepatol. 13 (1998) 643-650.

\section{Biographies}

Zhiwei Gao is currently a master candidate, joint-educated, at Zhejiang Ocean University, and Yantai Institute of Coastal Zone Research, Chinese Academy of Sciences since 2015. He received his BS from Hebei University of Technology, in 2015. His current research interests focus on the development of functional fluorescent probes for bioimaging.

Jingya Sun is currently a professor at Zhejiang Ocean University. Her research interests focus on the development and utilization of Applied Chemistry and Marine Biological Resources.

Min Gao is currently a doctoral candidate, under the guidance of Prof. Lingxin Chen, at Yantai Institute of Coastal Zone Research, Chinese Academy of Sciences and has been since 2013. She received her BS from Linyi University, in 2013. Her current research interests focus on the development of functional fluorescent probes for bioimaging.

Fabiao Yu is currently an associate professor at Yantai Institute of Coastal Zone Research, Chinese Academy of Sciences. He received his $\mathrm{PhD}$, joint-educated, at Dalian University of Technology, and Dalian Institute of Chemical Physics, Chinese Academy of Sciences, in 2013. His research interests focus on functional probe molecules (fluorescence and phosphorescence analysis), theranostics, and organic functional materials.

Lingxin Chen has been a professor at Yantai Institute of Coastal Zone Research, Chinese Academy of Sciences, since 2009. He obtained his Ph.D. in analytical chemistry at Dalian Institute of Chemical Physics, Chinese Academy of Sciences, in 2003. During 2004 - 2009, he worked at Department of Chemistry, Tsinghua University, and Department of Applied Chemistry, Hanyang University, respectively. His research interests include the studies of novel properties of materials such as functionalized nanoparticles \& functional probe molecules for developing nanoscale biochemica analysis methods and molecular imprinting-based sample pretreatment technology.

Qingguo Chen is currently an associate professor at Zhejiang Ocean University. He received his $\mathrm{PhD}$, at Ocean University of China, in 2012. His research interests focus on functional materials in environment pollution treatment. 